\title{
EPISTEMOLOGI FIKIH KELAUTAN ULAMA NUSANTARA
}

(Konstruksi Pemikiran Kiai Anwar Batang atas Kehalalan Kepiting)

\section{EPISTEMOLOGY OF MARINE FIQH OF ARCHIPELAGO ULAMA}

\author{
(Kiai Anwar Batang's Thought Construction Studyfor Halal Crab)
}

\author{
Zaimuddin ${ }^{1}$, Athoillah Islamy ${ }^{2}$ \\ 1Pascasarjana UIN Sunan Kalijaga, ${ }^{2}$ IAIN Pekalongan \\ (E-mail : zaimahya07@gmail.com¹ ; athoillahislamy@yahoo.co.id²)
}

\begin{abstract}
Although crab is seen as an animal that has great benefits for the health of the human body, there are differences among scholars regarding the law of consuming it. This study intends to explore and identify the construction of Islamic legal thought by one of the Javanese coastal ulama in the $19^{\text {th }}$ century AD regarding the legal status of the crab halal. The cleric in question is named Kiai Muhammad Anwar or who is often called Kiai Anwar Batang. This research is a qualitative research in the form of literature review. This Islamic legal research is included in the category of normative-philosophical Islamic law research. The data source is the Book of Aisyul Bahri by Kiai Anwar Batang, and various relevant scientific researches. The approach used is a philosophical approach to Islamic law by using a systems approach as proposed by Jasser Auda. This study concludes that the Islamic legal thinking of Kiai Anwar Batang regarding the halal status of crab is built on a universal interpretation of the legal message in verse 96 of the al-Maidah letter and is strengthened by various opinions of scholars regarding halal law for all types of aquatic animals. However, it does not stop at the approach to interpretation of the nas, Kiai Anwar Batang also conducts empirical research in the field with observations of the life of crab. He saw that crab is animal that can only live briefly on land, not animal that live in two realms (water and land).Therefore, it is halal for consumption.
\end{abstract}

Keywords: Epistemology, figh, marine, archipelago ulama

\section{ABSTRAK}

Meski kepiting dipandang sebagai hewan yang mengandung manfaat besar bagi kesehatan tubuh manusia, akan tetapi terjadi perbedaan di kalangan para ulama terkait hukum mengkonsumsinya. Penelitian ini bermaksud untuk mengeksplorasi dan mengidentifikasi konstruksi pemikiran hukum Islam salah seorang ulama pesisir Jawa Abad ke 19 M terkait status hukum kehalalan kepiting. Ulama yang dimaksud bernama Kiai Muhammad Anwar atau yang sering disebut Kiai Anwar Batang. Penelitian ini merupakan penelitian kualitatif yang berupa kajian pustaka. Penelitian hukum Islam ini masuk kategori penelitian hukum Islam normatiffilosofis. Sumber data yakni Kitab Aisyul Bahri karya Kiai Anwar Batang, dan pelbagai peneitian ilmiah yang relevan. Pendekatan yang digunakan adalah filsafat hukum Islam dengan menggunakan pendekatan sistem yang dicetuskan Jasser Auda. Penelitian ini menyimpulkan pemikiran hukum Islam Kiai Anwar Batang atas status kehalalan kepiting dibangun atas interpretasi universal terhadap pesan hukum pada ayat 96 dari surat al-Maidah dan diperkuat oleh pelbagai pendapat ulama terkait hukum halal atas semua jenis hewan air. Namun tidak berhenti pada pendekatan interpretasi nas, Kiai Anwar Batang juga melakukan penelitian empiris di lapangan dengan observasi terhadap kehidupan kepiting. la melihat bahwa kepiting merupakan hewan yang hanya dapat hidup sebentar di darat, bukan hewan yang kehidupanya di dua alam (air dan darat). Oleh Sebab itu, halal untuk dikonsumsi.

Kata Kunci : Epistemologi, fikih, kelautan, ulama nusantara 


\section{PENDAHULUAN}

Eksistensi hukum Islam di Indonesia telah ada sejak ajaran Islam tiba di Nusantara (Ali Sunarso, 2018: 10). Sejak itulah, hukum Islam telah menjadi bagian dari sistem hukum yang berlaku di Bumi Nusantara, khususnya bagi kehidupan umat Islam (S Sarkowi, A Susilo, 2020: 14), baik dalam persoalan ritualitas maupun interaksi sosial (Athoillah Islamy, 2020: 9). Namun demikian karakteristik hukum Islam (figh) sebagai produk pemikiran ijtihad (Abd Wahhab Khallaf, 1947: 216-217) dalam ranah praksisnya tidak jarang menimbulkan pro kontra atas legitimasi hukum persoalan di tengah kehidupan umat Islam (Khoirul Asfiyak, 2020: 67). Hal demikian tidaklah mengherankan mengingat pendapat hukum Islam sendiri sejatinya merupakan produk aktivitas intelektual ulama terhadap landasan normatif Islam (baik al-Qur'an maupun Hadis) di suatu tempat, masa dan kondisi sosial yang berbeda-beda. Oleh sebab itu, menjadi niscaya jika pendapat hukum Islam tidaklah tunggal, melainkan beragam meski berpijak pada teks normatif nas yang sama (Athoillah Islamy, 2007: 149).

Problem praksis hukum Islam di atas dapat dilihat dalam sejarah hukum Islam di Nusantara, yaknii tepatnya pada kisaran abad XX, pernah terjadi perdebatan sengit antar para ulama terkait status hukum atas kehalalan dan keharaman mengkonsumsi pelbagai jenis hewan air. Pada saat itu, komunitas ulama Nusantara yang berada di Hijaz pernah dituduh mengkonsumsi ular lantaran mereka mengkonsumsi belut yang bentuknya mirip dengan ular. Dalam rangka menolak tuduhan itulah, pada akhirnya salah seorang ulama Nusantara bernama Syaikh Muhammad Mukhtar menulis kitab yang secara khusus mengupas hewan belut beserta status hukum mengonsumsinya. Kitab tersebut diberi judul As-Shawaiq al-Muhriqah Ii al-Awham AlKadzibah fi Bayani hilli al-Belut wa ar-Raddu 'ala Man Harramahu.(Republika, 2016: 1).

Selain belut, terdapat juga jenis hewan lainnya yang hukum mengkonsumsinya juga menuai perdebatan sengit, yakni kepiting. Padahal kepiting sendiri merupakan salah satu jenis makanan yang digemari masyarakat nusantara. Selain rasanya lezat, kepiting juga mengandung beragam gizi penting, seperti energi, protein, lemak, kalsium, fosfor, vitamin A, vitamin B1, dan kolesterol. Di samping itu, kepiting mengandung asam folat, omega-3, vitamin B kompleks, serta mineral (Husnul Haq, 2019: 1). Namun di balik manfaat yang dikandungnya menuai perbedaan pendapat para ulama terkait hukum mengkonsumsinya. Mazhab Hanafi dan Shafi'i misalnya, menghukuminya haram. Sementara itu, Mazhab Maliki, memberikan status hukum mubah karena tidak ada penjelasan larangan khusus atas mengkonsumsinya dalam nas (al-Qur'an dan Hadis). Sedangkan Mazhab Hanbali menyatakan setiap hewan laut yang dapat hdup di darat, seperti anjing laut dan burung laut, maka harus disembelih terbih dahulu sebelum dikonsumsi. Berbeda dengan hewan laut yang tidak berdarah seperti kepiting, maka halal dikonsumsi tanpa disembelih terlebih dahulu (Fatwa dan Tausiyah Majelis Ulama Indonesia Provinsi Khusus Daerah Ibu Kota Jakarta 2016 : 118).

Tidak sekedar perdebatan pendapat hukum mengkonsumsi kepiting, jika merujuk kepada kitab Aisyul Bahri, bahkan sudah sampai pada taraf mengafirkan orang yang mengahalalkan kepiting. Merespons polemik ijtihadi tersebut, Kiai Muhammar Anwar Batang (selanjutnya ditulis Kiai Anwar Batang) merupakan seorang ulama nusantara yang dikenal faham tentang pelbagai jenis hewan seperti kepiting. Ia menulis sebuah kitab yang bernama Aisyul Bahri. Melalui kitabnya tersebut, ia mencoba meluruskan pendapat yang sudah viral saat itu dengan membangun argumntasi hukum Islam berdasarkan berberapa hal, mulai dari menyuguhkan data lapangan sampai pada landasan argumen Qur'anik. (Zaim Ahya, 2018: 1).

Penelitian ini berupaya mengeksplorasi sekaligus mengidentifikasi konstruksi pemikiran hukum Islam Kiai Anwar Batang atas status hukum konsumsi kepiting yang dituliskannya dalam Kitab Aisyul Bahri. Penelitian ini penting dilakukan untuk menunjukan salah satu kontribusi pemikiran hukum Islam ulama pesisir dalam hal epistemologi hukum Islam atas status hewan laut yang berupa kepiting khususnya, dan pelbagai 
hewan laut atau air pada umumnya. Adapun riset ilmiah sebelumnya tentang seputar kajian pemikiran hukum Islam Kiai Anwar Batang atau terkait pembahasan kitabnya (kitab Aisyul Bahri) dapat dikatakan masih sangat minim. Namun demikian berdasarkan penelusuran penulis setidaknya terdapat dua penelitian sebelumnya yang relevan dengan penelitian ini.

Sebagamana penelitian tesis oleh Mahmud Yunus Mustofa. Melalui pendekatan sejarah sosial intelektual, ia menuturkan bahwa kitab 'Aisyul Bahrikarya Kiai Anwar Batang merupakan bentuk peneguhan tradisi intelektualisme Islam di Bumi Nusantara yang cukup kental dengan mazhab Syafi'iyah. Di samping itu, keberadaan kitab Aisyul Bahriditulis berdasarkan kultur kognitif dan kebutuhan masyarakat pesisir Jawa pada masanya (Muhammad Yunus Mustofa, 2019: 107). Selain Yunus, penelitian Kurdi Fadal menyebut Kiai Anwar Batang memahami karakterisitik hewan laut yang kemudian menjadi bagiani pijakan ijtihad hukumnya terkait hukum mengkonsumsi hewan-hewan laut (Kurdi Fadal, 2020: 328).

Berdasarkan uraian latar belakang masalah di atas, maka dalam penelitian ini dirumuskan pertanyaan penelitian pokok. [1] Bagaimana konstruksi penggalian hukum Islam (istinbat alhukm) Kiai Anwar atas Kehalalan Kepiting dalam pendekatan sistem hukum Islam Jasser Auda? [2] Apa implikasi teoritik atas konstruksi pemikiran Hukum Islam Kiai Anwar terkait kehalalan kepiting?

\section{KAJIAN TEOR}

Kerangka Filsafat Sistem Sebagai Pendekatan Hukum Islam

Kendatipun keberadaan maqasid shariah dalam konteks kajian hukum Islam kontemporer dipandang sebagai pendekatan hukum Islam baru (Syamsul Anwar, 2015: 71). Namun dalam ranah aplikasinya dapat menimbulkan kesukaran jika konsepnya tidak mengalami pembaharuan (Aprizal Sulthon Rasyidi, 2020:46). Dalam konteksi ini, (Amin Abdullah, 2012: 316) juga mengusulkam pentingnya melakukan integrasi konsep maqasid shariah dengan pendekatan sejarah dan filsafat. Integrasi tersebut tidak lain dimaksud- kan agar keberadaan maqasid dapat menjadi pendekatan hukum Islam yang aplikatif, kontekstual dan responsif dalam merespon perkembangan problem hukum Islam yang ada

Apa yang disarankan oleh Amin Abdullah di atas juga difikirkan oleh seorang pakar filsafat hukum Islam kontemporer yang bernama Jasser Auda. Menurut Auda sebagaimana dikutip Hengky Ferdiansyah, bahwa untuk menyelesaikan problem hukum Islam yang berkembang di tengah kehidupan masyarakat, maka penting mengelaborasikan pendekatan hukum Islam dengan pelbagai teori ilmu sosial agar melahirkan pendekatan hukum Islam yang holistik. Dalam konteks inilah, Auda mengusulkan pentingnya pendekatansistem dalam mengembangkan konsep maqasid sharia sebagai pendekatan hukum Islam modern. Menurutnya, pendekatansistem merupakan pendekatan holistik yang dapat memandang setiap entitas sebagai satu kesatuan sistem (Hengki Ferdiansyah, 207: 105). Menurut Auda, terdapat enam fitur dalam filsafat sistem yang dapat dijadikan sebagai basis pendekatan hukum Islam, antara lain, sebagai berikut.

Pertama, watak kognisi (cognitive nature). Auda menjelaskan bahwa watak kognisi merupakan komponen dalam sistem hukum Islam yang harus dan penting disadari. Fitur watak kognisi ini meniscayakan validitas hukum Islam sebagai produk pemikiran hukum yang bersumber dari dialektika kognisi dan realitas, memungkinkan memiliki kelemahan (Auda, 2008: 46).

Kedua, keseluruhan (wholeness). Bagi Auda, paradigma menyeluruh yang mengkorelasikan antar pelbagai komponen hukum Islam merupakan hal yang harus diperhatikan dalam pendekatan hukum Islam. Hal demikian disebabkan ia melihat adanya kecenderungan penggunaan logika hukum Islam klasik yang reduksionis, dikotomis dan atomistis (Auda: 197-198).

Ketiga, keterbukaan (openness). Menurut Auda, penting menjadikan hukum Islam sebagai sistem hukum yang terbuka. Ia menuturkan, untuk mewujudkan hal tersebut dibutuhkan pengembangan instrument pada pelbagai landasan filosofis maupun metode hukum Islam klasik (Auda: 202). 
Keempat, relasi hirarkis relasional. Dalam pandangan Auda, kategorisasi berdasarkan konsep merupakan kategorisasi yang tepat digunakan sebagai paradigma pembaharuan metodologi hukum Islam. Menurutnya, katagorisasi tersebut merupakan metode integratif dan sistematik, bukan sekedar menentukan benar atau salah, melainkan dapat memuat pelbagai kriteria yang dapat bekerja secara simultan (Auda: 48-49).

Kelima, multi dimensi. Auda menjelaskan bahwa sistem hukum Islam merupakan sistem hukum yang memiliki dimensi beragam. Oleh karenanya, Auda memandang paradima oposisi binner tidak perlu ada dalam pendekatan hukum Islam. Hal ini disebabkan Auda menilai pelbagai kriteria dalil hukum yang dianggap kontradikitif sejatinya dapat saling melengkapi (Hengki Ferdiansyah: 126-127).

Keenam, kebermaksudan. Auda menjelaskan bahwa keberadaan maqasid shariah merupakan fitur inti yang menjadi tujuan dalam pensyariatan hukum Islam. Oleh karena itu, keberadaan maqasid shari'ah tidak boleh terabaikan dalam penetapan hukum Islam.la menambahkan keberadaan maqasid shariah dalam sistem hukum Islam menempati posisipurpose (ghayat) yang tidak bersifat monolitik dan mekanistik. Dengan kata lain, sistem hukum Islam harus dapat menghasilkan pelbagai tujuan hukum Islam melalui berbagai cara, kondisi dan hasil tujuan yang beragam dengan tetap mendasarkan pada sumber utama hukum Islam (al-Qur'an dan Hadits), tidak sekedar pemikiran mujtahid (Auda: 54-55). Menurut Auda, untuk menjadikan keberadaan maqasid sebagai pendekatan hukum Islam yang tidak bersifat monolitik dan mekanistik, maka penting adanya perluasan dimensi kemaslahatan maqasid shariah dalam segala tingkatannya. Sebagai contoh, konsep hifz nafs (proteksi jiwa) dikembangkan menjadi proteksi terhadap kehormatan manusia atau hak-hak kemanusian. Konsep hifz aql (proteksi akal) menjadi penghormatan atas kebebasan berfikir ilmiah. Konsep hifz din (proteksi agama) menjadi proteksi atas kebebasan berkeyakinan. Kemudian konsep hifz nasl (proteksi keturunan) menjadi proteksi kehidupan keluarga), dan lain sebagainya (Auda: 21-24).
Dalam penelitian ini, pendekatan sistem hukum Islam di atas akan digunakan sebagai teori analisis dalam mengeksplorasi, menganalisis sekaligus mengidentifikasi kontruksi pemikiran hukum Islam Kiai Anwar Batang terkait status kehalalan hewan laut dalam Kitab Aisyul Bahri, baik pada ranah filsafat maupun teori produk) pemikiran hukum Islam yang dibangunnya

\section{METODE PENELITIAN}

Penelitian ini merupakan kategori penelitian kualitatif yang berupa kajian pustaka (library research) (Lexy J. Moleong, 2017: 6) (Pascasarjana UIN Walisongo, 2018: 35). Jenis penelitian hukum Islam dalam penelitian ini masuk dalam kategori penelitian hukum Islam normatiffilosofis (Atho Mudzhar, 2012: 95-96). Kategori tersebut dimaksudkan untuk mengkaji konstruksi pemikiran hukum Islam Kiai Anwar Batang terkait status kehalalan hewan laut dalam Kitab Aisyul Bahri, baik pada ranah filsafat maupun teori (produk) pemikiran hukum Islam yang dibangunya. Sumber data utama penelitian yang digunakan yakni Kitab Aisyul Bahri karya Kiai Anwar Batang, dan sumber data sekunder menggunakan pelbagai penelitian ilmiah yang relevan dengan pokok pembahasan dalam penelitian ini, antara lain Tesis karya Muhammad Yunus yang berjudul Transmisi Pendidikan Fiqih Nusantara Pada Masyarakat Pesisir (Telaah Kitab Aisyul Bahri Karya Kiai Anwar Batang) Universitas Wahid Hasyim Semarang tahun 2019. Kemudian Jurnal karya KurdiFadal yang berjudul "Aisy AlBahr:Karya Intelektual Ulama Pesisir Jawa Awal Abad XX Seputar Hewan Laut", dalam Jurnal Lektur Keagamaan, Vol. 18, No. 2 tahun 2020.

Jenis pendekatan penelitian ini yakni pendekatan filosofis (filsafat hukum Islam) dengan menggunakan pendekatan sistem hukum Islam yang dicetuskan oleh J asser Auda. Sementara itu, sifat pendekatan penelitian ini adalah deskriptif-analitik, yakni mendeskripsikan kontruksi pemikiran hukum Islam Kiai Anwar Batang. Kemudian dianalisis untuk diidentifikasi. Dalam ranah aplikasinya, penulis mendiskripsikan data inti yang menjadi objek pembahasan, yakni terkait proses penggalian hukum Islam yang 
dilakukan oleh Kiai Anwar dalam Kitab Aisyul Bahri terkait kehalalan kepiting. Kemudian dianalisis menggunakan berbagai instrumen fitur dalam teori pendekatan sistem hukum Islam J asser Auda, antara lainfitur kognisi, keterbukaan, keseluruhan, hirarkis relasional, multi dimensional, dan kebermaksudan. Melalui berbagai fitur tersbut diharapkan dapat mengeksplorasi sekaligus mengidentifikasi konstruksi penggalian hukum Islam Kiai Anwar terkait status kehalalan Kepiting.

\section{PEMBAHASAN}

Diaspora Intelektual, Aktifitas Sosial, dan Karya Kiai Anwar Batang

Keberadaan biografi Kiai Anwar Batang sampai saat ini masih misterius, belum ada yang menjelaskan secara komprehensif. Kendati demikian, dari pelbagai sumber menyatakan beberapa informasi tentang asal usul Kiai Anwar. Kiai Dimyati Rois, yang akrab dipanggil Mbah Dim, pernah menceritakan bahwa kehidupan Kiai Anwar satu masa dengan Kiai Nawawi Banten dan Kiai Kholil Bangkalan. Mbah Dim menuturkan, Kiai Anwar pernah melakukan pertemuan bersama para kiai terkenal di Alas Roban Batang Jawa Tengah. Para kiai tersebut adalah Kiai Nawawi Banten (1813-1897 M), Kiai Shalih Darat (1820-1903), Kiai Khalil Bangkalan (18201925). Menurut Mbah Dim, pertemuan Alas Roban Batang tersebut terjadi pada tahun $1895 \mathrm{M}$ (Kurdi Fadal, 2020 : 312)

Jika merujuk kitab Aisyul Bahrikarya Kiai Anwar Batang dengan tebal empat puluh satu halaman menunjukan bahwa kitab tersebut selesai ditulis pada tanggal 24 Sofar tahun $1339 \mathrm{H}$ bertepatan dengan tahun $1920 \mathrm{M}$ (Muhammad Anwar, 2017: 41). Oleh sebab itu, dapat disimpulkan bahwa Kiai Anwar Batang merupakan sosok ulama yang hidup pada rentang masa akhir Abad ke 18 dan awal Abad ke-19. Sebelum masa Kiai Anwar Batang, Pada kisaran awal Abad ke 19 sebenarnya di daerah Batang sendiri tepatnya di desa Kalisalak Kecamatan Limpung terdapat seorang ulama pendakwah karismatik yang kemudian dinobatkan sebagai salah satu Pahlawan Nasional (Indonesia) pada tahun 2005 oleh Presiden Susilo Bambang Yudiono. Ulama Karismatik tersebut bernama K.H. Ahmad Rifai (1786-1871M) (Abdul Basit Atamimi, Athoillah Islamy, 2019: 128-129).

Dalam kitab Aisyul Bahri, tertera nama lengkap Kiai Anwar Batang, yakni Muhammad Anwar yang berasal dari Kauman yang merupakan salah satu kecamatan di Kabupaten Batang Provinsi Jawa Tengah. Penting diketahui bahwa kabupaten Batang merupakan salah satu kabupaten di Provinsi Jawa Tengah yang memiliki perpaduan keadaan geografis antara daerah pesisir, dataran rendah dan pegunungan. Wilayah pesisir Kabupaten Batang terdiri dari enam kecamatan yaitu Kecamatan Batang, Kecamatan Kandeman, Kecamatan Tulis, Kecamatan Subah, Kecamatan Banyuputih, dan Kecamatan Gringsing. (Ahmad Ibnu Reza, Athoillah Islamy, 2020: 45). Oleh sebab itu, tidak menghernakan jika Kia Anwar sebagai seorang ulama yang tinggal di area dekat pesisir pantai di daerah Batang. Terlebih jika melihat pada bagian sampul kitab Aisyul Bahrijuga dijelaskan, bahwa Kiai Anwar merupakan seorang yang termasuk dalam komunitas nelayan (ahlu soidil bahri), dan jika melihat karyanya, maka dapat dikatakan ia termasuk ulama yang memiliki wawasan luas tentang hewan-hewan yang hidup di air dan hewan yang hidup di air dan darat sekaligus.

Identifikasi bahwaKiai Anwar Batang merupakan seorang nelayan juga dikuatkan oleh Pengasuh Pondok Pesantren Darul Ulum Tragung Kandeman Batang, yakni Kiai Zainal Iroqi (Seorang ulama yang disinyalir masih memiliki hubungan darah dengan Kiai Anwar) yang menyatakan bahwa kiai Anwar Batang merupakan seorang nelayan (Mammud Yunus, 2019: 41). Namun Kiai Iroqi menyatakan bahwa berdasrkan keterangan kakeknya, Kiai Anwar sebenarnya berasal dari Ceribon, hanya kemudian menikah dan tinggal di Batang.

Sementara itu terkait riwayat perjalanan intelektual Kiai Anwar Batang, terdapat sejumlah informasi yang menyatakan bahwa Kiai Anwar pernah melakukan rihlah intelektual ke Makkah. Selain itu, pada pelbagai acara publik, Kiai Haji Dimyati Rois juga sering berkisah tentang Kiai 
Anwar Batang. Menurut Kiai Dimyati, sekitar lima puluh tahun sebelum kemerdekaan Indonesia, terjadi pertemuan para ulama di Batang, tepatnya di rumah Kiai Anwar yang letaknya di Alas Roban Batang. Kiai Dimyati menyebut beberapa nama kiai besar yang hadir dalam pertemuan itu seperti Kiai Nawawi Banten dan Kiai Kholil Bangkalan. Dalam pertemuan tersebut, dilaksanakan istighasah atau doa bersama dengan membaca dzikir musabbi'at. Dzikir musabbi'at sampai sekarang masih diamalkan oleh Kiai Dimyati Rois.Biasanya dibaca bersama santri dan masyarakat setiap malam Jumat Kliwon di area Pondok Pesantren Alfadllu. Dzikir musabbi'at adalah kumpulan dari beberapa surat-surat pendek dalam al-Qur'an yang dibaca masingmasing tujuh kali. Surat-surat pendek tersebut meliputi surat al-Fatihah, al-Insyirah, al-Qodr, alIkhlas, al-Falaq dan an-Nas. Dalam karyanya yang berjudul Maroqil Ubudiyah, Kiai Nawawi Banten dengan mengutip Imam al-Ghazali dalam Ihya' Ulumuddin, juga menyebut istilah musabbi'at, namun dengan menambahkan kata al-'asyrahdan surat-surat yang yang dicantumkan di dalamnya juga tidak sama persis (Syaikh Nawawi al-Bantani, 2015: 34).

Keterangan di atas menunjukan bahwa Kiai Anwar bukanlah ulama yang jaringannya terbatas pada wilayah di mana ia hidup. Hal ini terlihat dari jaringan relasi pertemanannya dengan para u lama besar, seperti Kiai Nawawi Banten yang bergelar sayyid ulama hijaz (pemimpin ulama Hijaz) dan Kiai Kholil Bangkalan (guru para kiai pendiri Nahdlatul Ulama).

Di daerah Batang sendiri, terdapat dua tempat yang disinyalir sebagai makam beliau. Menurut sebagian pendapat menyatakan makam Kiai Anwar berada di komplek pemakaman umum di Kauman Batang. Saat penulis melakukan penelusuran, memang ada salah satu makam di dekat pohon yang di bawahnya terdapat papan bertuliskan huruf Arab, "Muhammad Anwar". Di daerah tersebut juga terdapat musala dengan nama "al-Anwar".

Sedangkan menurut pendapat lain, makam Kiai Anwar terletak di wilayah Alas Roban, tepatnya di Desa Sengon Kecamatan Subah Kabupaten Batang, yakni tidak jauh dari jalan tol SemarangBatang. Makam tersebut terletak di tengah kebun di pinggir sawah, dan bukan pemakaman umum. Menurut keterangan warga setempat, makam tersebut merupakan makam tua yang sudah ada sejak dulu. Dalam beberapa tahun terakhir, makam itu ramai karena diyakini sebagai tempat peristirahatan terakhir Kiai Anwar. Saat penulis mengunjunginya, di sekitarnya ada semacam baliho yang bertuliskan, "Makam Kiai Anwar Batang Sohibu Aisyul Bahri".

Sekali lagi identitas sebagai seorang fagih (ahli fikih) dan juga nelayan yang pada diri Kiai Anwar rasanya suli dibantah. Mengingat dalam kitab yang ditulisnya (Aisyuh Bahri), ia juga dapat menjelaskan gambaran secara detail beberapa hewan yang hidup di air dengan apik berdasarkan observasinya di lapangan (Muhammad Anwar, 2017: 1-2).

Konstruksi Metodologis Hukum Islam Kiai Anwar Atas Status Kehalalan Kepiting

Tidak dapat dipungkiri, aktivitas ijtihad dalam menjawab persoalan hukum yang berkembang senantiasa dibutuhkan umat (Hamid Harasani, 2013: 361). Said Agil Husin AlMunawar menuturkan terdapat dua hal yang menjadikan pentingya ijtihad. Pertama, tidak semua hukum persoalan dijelaskan dalam landasan teologis, baik Qur'an maupun Hadis. Kedua, hukum dalam nas sudah berhenti, sedangkan problem hukum yang dihadapi umat senantiasa berkembang (Said Agil Husin Al Munawar, 1998: 59-60). Atas dasar inilah menjadi niscaya jika peran ijtihad harus senantiasa dihidupkan dalam menjawab pelbagai problem hukum yang dinamis. Dengan kata lain, pintu ijtihad tidak pernah tertutup, melainkan senantiasa terbuka (Athoillah Islamy, 2021: 43).

Namun penting diketahui bahwa sebagai produk hasil ijtihad, keberadaan pendapat hukum Islam terkait hukum sebuah kasus seringkali plural, yakni tidak tunggal meskipun berpijak pada landasan nas yang sama, baik al-Qur'an maupun Hadis (Athoillah Islamy, 2020: 50). Terlebih dalam konteks pendapat hukum terkait persoalan yang tidak disinggung dalam nas secara eksplisit, maka ragam pendapat menjadi 
sebuah keniscyaan yang sulit dihindarkan.

Dalam membangun argumentasi hukum atas kehalalan pelbagai hewan laut, termasuk di antaranya kepiting, Kiai Anwar Batang merujuk kepada ayat al-Quranyang secara spesifik membahas kehalalan mengonsumsi hewan yang hidup di laut (bahr), yakni surat al-Maidah [5] ayat 96. Namun tidak melalui penalaran bayani (Mardani, 2013: 261-332) semata, ia juga berupaya melakukan penelitian empiris dengan terjun langsung melakukan observasi terhadap hal ihwal kehidupan hewan laut.

Sebagaimana pada kasus kehalalan kepiting, Kiai Anwar terlebih dahulu menjelaskan bentuk fisik, dan pola hidup hewan tersebut dari cara mencari makanan dan habitatnya. Kemudian ia menarik sebuah kesimpulan, bahwa kepiting termasuk katagori hewan yang hanya hidup di air, meski kadang terlihat di darat. Untuk menguatkan argumentasinya, Kiai Anwar menyuguhkan tiga tipologi kehidupan hewan air ketika berada di darat. Pertama, hewan air yang ketika di darat hidupnya seperti hewan yang disembelih (hayyi madzbuhin), sehingga jika dibiarkan di darat akan mati seperti ikan lele. Kedua, hewan air yang dapat bertahan hidup di darat, namun tidak langgeng (aisyu hayyin la yadum) seperti halnya kepiting. Ketiga, hewan air namun juga bisa hidup di darat secara langgeng (aisyun daimun) seperti buaya (Muhammad Anwar, 2017: 3). Dari sini terlihat bahwa Kiai Anwar merupakan sosok ulama yang memiliki kompetensi mendalam terkait hal ihwal kehidupan hewan air.

Menurut Kiai Anwar, dari tiga tipologi di atas, tipologi terakhirlah yang dihukumi haram karena bukan termasuk hewan yang hanya hidup di air, melainkan sekaligus darat. Sedangkan dua tipologi yang disebut sebelumnya termasuk hewan yang hanya dapat bertahan lama hidup di air, maka hukumnya halal. Perihal kehalalan hewan yang hidup di air (dalam hal ini kepiting), Kiai Anwar merujuk kepada pendapat sebagian ulama yang menyatakan bahwa bahwa setiap hewan yang hanya hidup di laut (bahr) halal bangkainya. Kiai Anwar lalu melancarkan kritiknya atas beberapa fatwa yang menyatakan haramnya kepiting. Tidak sampai di situ saja, Kiai Anwar juga merujuk kepadalmam Syafi'i yang menurutnya memberi nash bahwa hewan laut yang hanya hidup di laut halal dikonsumsi dengan alasan umumnya ayat.

Cara membangun argumentasi seperti di atas juga diterapkan Kiai Anwar ketika membahas hewan-hewan yang lain yang menurutnya berstatus halal. Dalam ranah aplikasinya, ia mengawali dengan menjelaskan bentuk fisik dan pola hidup hewan terkait. Kemudian menjelaskan katagorisasi apakah hewan tersebut termasuk hewan laut atau tidak. Selanjutnya, merujuk pendapat fikih yang menyatakan halalnya hewan yang hanya hidup di air, dan terakhir ia menyatakan halalnya hewan yang hanya hidup di air berdasarkan ayat al-Quran yang menurutnya menunjukkan keumuman (Muhammad Anwar, 2017:6).

Berpijak pada keterangan di atas, terdapat beberapa langkah penafsiran hukum yang dilakukan oleh Kiai Anwar, sebagai berikut.

Pertama, Kiai Anwar memahami ayat alQur'an yang menjelaskan tentang hukum halal mengkonsumsi hewan laut sebagai ayat yang umum ('am), yakni surat al-Maidah [5] ayat 96 yang berbunyi "Ukhilla lakum saidul-bakhri wa taaamuhuu matâ'al lakum wa lis-sayyârah, wa kurrima 'alaikum caidul-barri mâ dumtum kurumâ, wattaqullâhalladhî ilaihi tukhsyaruun", (Dihalalkan bagimu binatang buruan laut dan makanan (yang berasal) dari laut sebagai makanan yang lezat bagimu, dan bagi orang-orang yang dalam perjalanan, dan diharamkan atasmu (menangkap) binatang buruan darat, selama kamu dalam ihram. Dan bertakwalah kepada Allah Yang kepada-Nya-lah kamu akan dikumpulkan).

Dalam Ushul Fikih, lafaz 'am merupakan kata yang memuat makna seluruh bagian dari kandungan lafaz, sesuai pengertian kebahasaan tanpa pengecualian oleh kata lain. Artinya, lafaz 'am mencakup seluruh sesuatu yang dikandungnya tanpa pengecualian. Oleh karena itu, lafaz 'am hanya memiliki satu pengertian, walaupun ia mencakup beberapa satuan. Meski demikian, lafaz 'am memiliki pendamping, yakni lafazkhash. Dengan kata lain, lafaz 'am tidak selalu bersifat universal tanpa batas. Hal demikian disebabkan lafaz 'am itu sendiri terbagi menjadi beberapa katagori. Pertama, lafaz 'am yang 
mencakup segala sesuatu yang menjadi cakupannya tanpa terkecuali (al- 'Am al-Istigroqy). Kedua, lafaz am yang tidak mencakup bagiannya satu demi satu, namun mencakupnya secara umum (al-'Am al-Majmu'iy). Ketiga, lafaz 'am yang keumumannya bisa diwakili salah satu dari anggota yang dicakupnya (al-Am al-Badaly) (M Quraish Shihab, 2013: 180). Berdasarkan tiga klasifikasi tersebut, Kiai Anwar terlihat memahami surat al-Maidah [5] ayat 96 sebagai lafaz 'am jenis pertama yaknial-'Am al-Istigrogy. Kiai Anwar meyakini bahwa suluruh hewan yang hanya bisa hidup di air halal hukumnya.Yang demikian ini juga diperkuat dengan beberapa keterangan yang dikutip oleh Kiai Anwar dari beberapa ulama terkait hukum halal semua hewan air.

Argumentasi hukum yang dibangun Kiai Anwar di atas terlihat bahwa ia menekankan kategori makna universal dari lafaz 'amdalam menginterpretasikan ayat 96 dari surat al-Maidah bukan makna parsialnya. Dalam hal ini, J asser Auda menyatakan bahwa kategorisasi berdasarkan konsep (concept-based categorizations) merupakan metode integratif, tidak sekedar menentukan benar atau salah, melainkan mencakup pelbagai kriteria yang dapat mengkreasikan sejumlah kategori secara simultan (Jasser Auda: 48-49). Implikasi dari fitur hirarki relasional (Interrelated Hierarchy) ini,yakni interpretasi hukum atas kandungan makna atau pesan hukum dalam lafaz tingkatan lafaz al-'Am al-Istigroqy lebih diprioritaskan dibandingkan penggunaan lafaz al'Am al-Majmu'iydan lafazal-Am al-Badaly. Oleh sebab itu, interpretasi status hukum seluruh jenis hewan yang habitat aslinya atau yang hanya dapat hidup di air dihukumi halal.

Penting diketahui Kiai Anwar Batangjuga menuturkan bahwa kata bahr tidak hanya dipahami sebagai air laut. Menurutnya, dengan merujuk kepada kamus, kata bahr dalam surat al-Maidah [5] ayat 96 itu mencakup segala macam air (muthlaqul ma'), baik air tersebut asin atau tawar, sedikit atau banyak, di laut atau di telaga, atau pun di kolam (Muhammad Anwar, 2017: 4). Dengan tafsiran Kiai Anwar ini, hewanhewan yang halal dikonsumsi bukan terbatas pada hewan yang hidupnya di air laut, tapi juga hewan yang hidup di air telaga, sungai, bahkan kolam. Singkatnya, dengan merujuk kepada ayat 96 surat al-Maidah, Kiai Anwar berpendapat segala hewan yang hanya hidup di air, hukumnya halal dikonsumsi.

Kedua, Kiai Anwar melakukan riset lapangan dalam menentukan status habitat kehidupan hewan, apakah termasuk kategori hewan laut atau tidak. Hal itu dapat dilihat ketika Kiai Anwar mendiskripsikan kepiting, ia mengatakan: "aku telah menyaksikannya berkali-kali, kepiting adalah hewan yang menetap di air, tempat makan dan mencari makannya juga di air" (Muhammad Anwar, 2017: 2). Alasan Kiai Anwar sampai melakukan penelitian lapangan sepertinya tidak lepas dari pemahaman atas surat al-Maidah ayat 96. Sebagaimana telah dijelaskan sebelumnya, bahwa ayat tersebut dipahami Kiai Anwar sebagai ayat yang menunjukkan makna umum sehingga mencakup seluruh hewan yang hidup di air. Namun al-Quran tidak menjelaskan secara detail hewan apa saja yang termasuk hewan laut (soidul bahr wa tha'amuhu), maka penelitiannyadi lapangan dengan mengamati gerak gerik hewan merupakan hal yang niscaya untuk dilakukan jika ingin mengetahui status hukum mengonsumsinya secara tepat. Tanpa penelitian lapangan secara seksama, dan hanya berdasar praduga atau pengamatan sekilas, kemungkinan salah dalam melakukan justifikasi hukum sangat besar.

Dalam menentukan status kepiting apakah ia termasuk hidup di air atau darat selain melakukan penelitian empiris sebagaimana telah dijelaskan di atas, Kiai Anwar Batang juga bersandar kepada tiga tipologi kehidupan hewan air ketika berada di darat, sebagaimana telah dijelaskan sebelumnya [1] Hewan air yang dapat bertahan di darah sebatas seperti bertahan hidupnya hewan darat ketika disembelih, [2] Hewan air yang dapat bertahan di darat, akan tetapi tidak lama. [3] Hewan air yang dapat hidup di darat sebagaimana ia hidup di air. Tipologi ini menjadi penting diketahui sebagai acuan menentukan apakah hewan air tersebut juga bisa hidup di darat sebagaimana ia hidup di air atau tidak. Bahkan, kalau membaca ulasan Kiai Anwar Batang, lantaran tidak mengetahui tiga tipologi 
ini, maka seorang syaikh melakukan kesalahan dalam mengatagorikan hukum suatu hewan, yang dalam hal ini adalah kepiting. Dengan pengamatan sekilas dan tanpa mengetahui tiga tipologi itu, hewan air seperti kepiting yang sebenarnya tidak dapat betahan lama di darat, hanya karena syaikh tersebut melihat sekilas hewan itu berada di darat, lalu menyimpulkan bahwa hewan tersebut bisa hidup di dua alam (Muhammad Anwar, 2017: 3).

Langkah Kia Anwar melakukan penelitian empiris di lapangan untuk melakukan verifikasi atas jenis hewan air yang dimaksud dalam pesan hukum al-Maidah ayat 96 , dapat dikatakan sebagai bentuk aktivitas ijtihad yang mencoba mendialogkan antara interpretasi kognitif seorang mujtahid dengan konteks empiris kasus hukum yang dihadapinya. Menurut Jasser Auda, watak kognisi (cognitive nature) merupakan sebuah komponen dalam sistem hukum Islam yang harus disadari dan dipahami. Oleh karenanya, validitas sebuah konklusi hukum Islam sebagai produk pemikiran ijtihad yang bersumber dari dialektika kognisi dan realitas memiliki sisi relativitas yang senantiasa dapat diperdebatkan validitasnya (Jasser Auda: 46). Paralel dengan pandangan Auda, Amina Wadud menuturkan untuk menemukan makna hukum dari suatu teks (ayat) penting memperhatikan tiga hal, yakni konteks, gramatikal teks dan world view yang berkembang (Athoillah Islamy, 2020: 28-29). Dengan demikian langkah interpretasi hukum yang dilakukan Kiai Anwar dengan melakukan verifikasi data empiris di lapangan menunjukan bahwa ia memandang pemikiran hukum Islam dapat diuji validitasnya kearah yang lebih lebih tepat dan baik sesuai dengan kondisi yang ada. Dengan kata lain, tidak hanya bersifat normatif dogmatis.

Jika dilihat dalam perspektif ilmu mantiq (logika), penelitian empiris yang dilakukan Kiai Anwar merupakan bentuk ikhtiar agar tidak terjadi kekeliruan maupun kesalahan dalam mengkonsepsi (tasawwur) sesuatu sebelum melakukan tasdiq (justifikasi hukum) (Bisri Mustofa, 1953: 9). Bahkan meski justifikasi hukum kebetulan tepat, tanpa adanya tasawwur terlebih dulu secara tepat, maka justifikasi atau tasdiq tersebut tidak bisa dianggap valid. Dalam persoalan kepiting misalnya, seseorang tidak dapat mengatakan kepiting termasuk hewan yang hidup di laut atau hewan yang hidup di darat sebelum ia sendiri mengetahui detail tentang kepiting

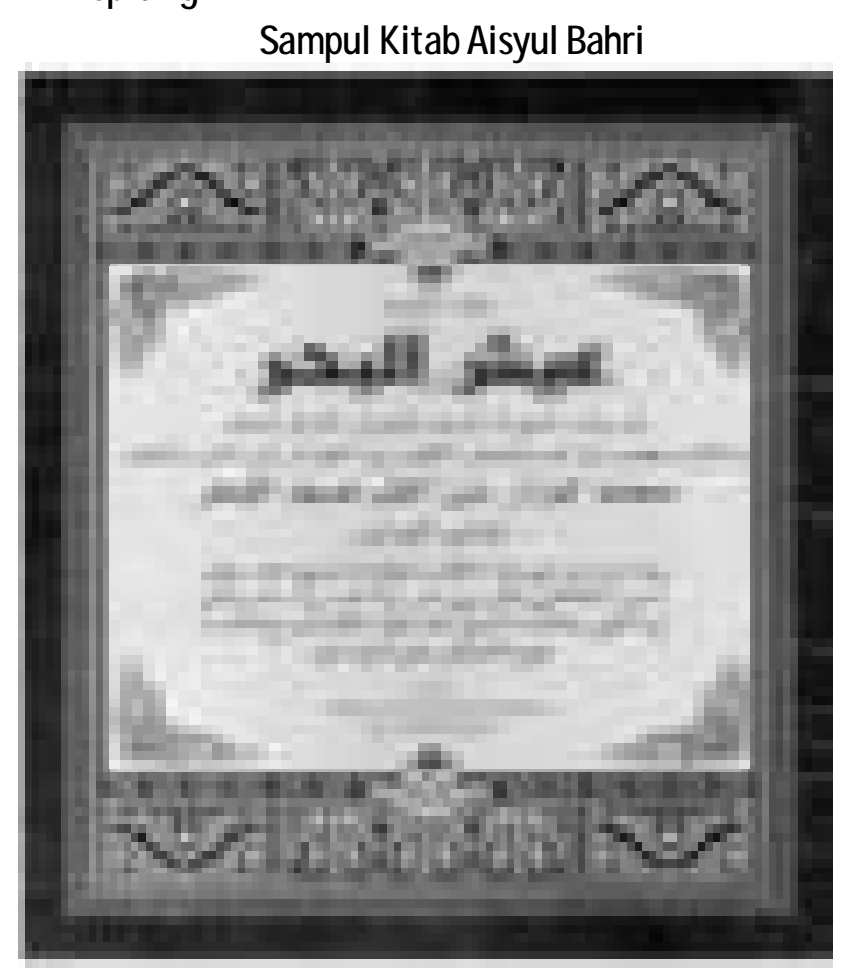

Halaman argumentasi Kiai Anwar tentang halalnya Kepiting

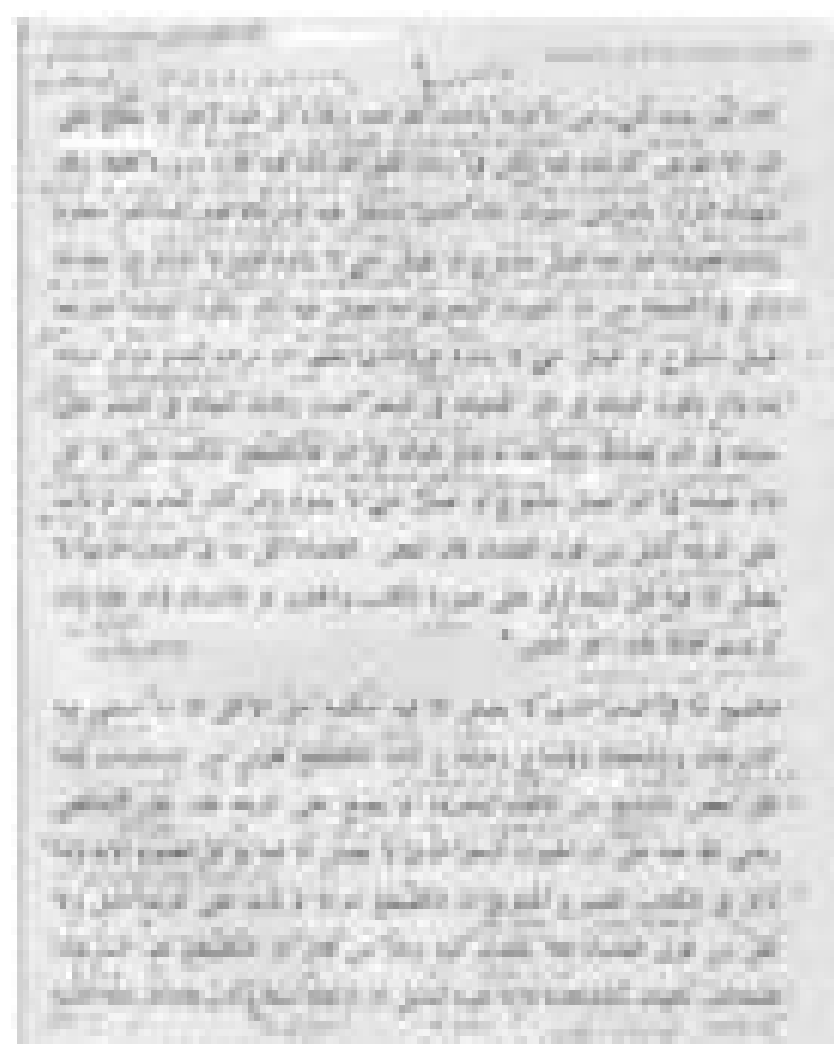


Refleksi Teoritik Atas Interpretasi Hukum Kiai Anwar Terkait Kehalalan Kepiting

Berdasarkan penjelasan interpretasi hukum

Kiai Anwar Batangatas kehalalan kepiting yang telah diuraikan sebelumnya, maka setidaknya dapat ditemukan beberapa implikasi teoritik yang dapat penulis uraikan, sebagai berikut.

Pertama, sebuah interpretasi hukum dalam nas tidaklah cukup didekati dengan pendekatan interpretasi literal (penalaran bayani), melainkan dalam konteks tertentu, seorang mujtahid harus mengetahui, baik dengan penelitian ke lapangan langsung seperti yang dilakukan Kiai Anwar Batang, atau dengan menggunakan data dari ahlinya. Kesimpulan di atas semakin menunjukan bahwa sejatinya hukum Islam merupakan sistem hukum yang terbuka. Kesimpulan demikian paralel dengan apa yang dinyatakan Auda, bahwa untuk menjadikan sistem hukum Islam yang terbuka dibutuhkan pengembangan instrument pada aspek metodologis (Jasser Auda: 202). Tidak berhenti di sini, Auda juga menambahkan diantara langkah pengembangan instrumen tersebut dapat melalui pembaharuan pada pandangan dunia (world view) hukum Islam, yakni pandangan dunia yang kompenten, kredibel dengan mengacu pada pemikiran ilmiah, bukan hanya dugaan(spikulasi). Implikasi dari pandangan dunia ini meniscayakan terjadinya dialog pendekatan hukum Islam dengan perkembangan ilmu pengetahuan yang berkembang (Hengki Ferdiansyah: 111-115).

Kedua, tipologi hukum konsumsi hewan air yang dapat hidup di darat.Tipologi tersebut digunakan Kiai Anwar sebagai pijakan interpretasi hukum. Pertama, hewan air yang dapat hidup di darat dengan waktu yang sebentar (tidak lama), maka masuk katagori hewan air yang hukumnya halal dikonsumsi. Tanpa adanya acuan tipologi tersebut, maka dapat saja mengkategorikan hewan air yang hanya dapat hidup sebentar di darat sebagai hewan yang habitatnya hidup di dua alam (air dan darat). Dengan kesimpulan tersebut, maka dapat dengan mudah menghukumi haram untuk dikonsumsi. Kesimpulan demikian juga menguatkan pendapat Kurdi Fadal yang menyebut Kiai Anwar Batang memahami karakterisitik hewan laut yang kemudian menjadi bagiani pijakan ijtihad hukumnya terkait hukum mengkonsumsi hewan-hewan laut (Kurdi Fadal, 2020: 328).

Ketiga, dengan ditemukannya argumentasi hukum atas kehalalan kepiting sebagaimana dalam perspektif Kiai Anwar, maka dapat menguatkan Fatwa hukum Islam modern di Indonesia. Fatwa yang dimaksud, yakni Fatwa Majelis Ulama Indonesia (MUI) yang menghalalkan kepiting untuk dikonsumsi. Namun dalam fatwa tersebut memberikan catatan bahwa kehalalan kepiting selama tidak menimbulkan bahaya bagi kesehatan manusia (Fatwa MUI Tentang Kepiting, 2002: 639-645).

Keberadaan tiga implikasi teoritik di atas menunjukan bahwa implikasi teoritik dari hasil temuan penelitian tidak hanya sebatas pada wilayah epistemologis, melainkan juga pada ranah ontologis dan aksiologis dari berbagai kajian ilmiah sebelumnya. Kajian ilmiah yang dimaksud yakni kajian yang relevan dengan pembahasan hukum mengkonsumsi hewan air yang sejatinya hanya dapat hidup sebentar di darat, seperti halnya kepiting dan pelbagai hewan laut (air) yang sejenisnya.

\section{PENUTUP}

\section{A. Simpulan}

Berpijak pada uraian pembahasan penelitian yang telah penulis uraiakan panjang lebar sebelumnya, maka dapat disimpulkan dua temuan besar penelitian, sebagai berikut.

Pertama, konstruksi pemikiran hukum Islam Kiai Anwar Batang atas status kehalalan kepiting berdasarkan interpretasi universal terhadap pesan hukum pada ayat 96 dari surat al-Maidah atas kehalalan seluruh hewan air. Namun tidak berhenti pada pendekatan interpretasi nas (ayat al-Qur'an), Kiai Anwar Batang juga melakukan penelitian empiris di lapangan dengan observasi terhadap kehidupan kepiting. Dalam konteks ini, ia melihat bahwa kepiting merupakan hewan yang hanya dapat hidup sebentar di darat. Dengan kata lain, bukan hewan yang habitat kehidupanya di dua alam (air dan darat), sehingga halal dikonsumsi.

Kedua, terdapat tiga implikasi teoritik hasil temuan penelitian ini. [1] Interpretasi 
hukum Islam tidaklah cukup didekati dengan pendekatan interpretasi literal nas (penalaran bayani), melainkan dalam konteks tertentu, penting mempertimbangkan kondisi empiris kasus. [2] Tipologi hewan air yang hanya dapat hidup di darat sebentar (tidak lama), maka hukumnya halal dikonsumsi. (3) Argumentasi hukum Kiai Anwar Batang atas kehalalan kepiting menguatkan Fatwa Majelis Ulama Indonesia (MUI) terkait setatus kehalalan kepiting

\section{B. Rekomendasi (Saran)}

Penulis memandang bahwa kebolehan mengkonsumsi kepiting juga penting dipertimbangkan aspek kemanfaatan (al-maslahah) dan kemafsadatan/ bahaya (al-mafsadah). Jika bagi kasus orang tertentu, akan menimbulkan bahaya bagi kesehatannya, seperti karena kadar kolestrol yang tinggi dalam kepiting. Maka dalam konteks tersebut, lebih baik tidak perlu mengkonsumsi, bahkan dapat masuk kategori haram jika sangat fatal dampaknya bagi yang mengkonsumsi. Dalam konteks ini, dapat berlaku dua kaidah hukum Islam (qawaid fiqhiyah) yang berbunyi dar'ul mafasid muqoddamun ala jalbil masalih (menolak bahaya lebih diperioritaskan dari mengambil kemanfaatan/ kemaslahatan). [ $\alpha$ ]

\section{DAFTAR PUSTAKA}

Abdullah, M. Amin. (2012). "Bangunan Baru Epistemologi Keilmuan Hukum Islam, Asy-Syir'ah: J urnal IImu Syariat dan Hukum", Vol. 46. II, 316.

Al Munawar, Said Agil Husin (1998)."Konsep Maslahah Sebagai Salah Satu Sumber Perundangan Islam", Jurnal Islamiyyat, Vol. 18, 59-60.

al-Bantani, Nawawi. (2015). Maraqil Ubudiyah, al-Haramain Indonesia, 34.

Anwar, Muhammad, (2017). Aisyuh Bahri, Pondok Pesantren Darul Ulum Tragung Kandeman Batang, 3, 4, 6, 41.

Anwar, Syamsul. (2015). Maqashid Shari'ah dalam Metodologi Ushul Fikih dalam Fikih Kebinekaan, Bandung, Mizan Pustaka, 71

Asfiyak, Khoirul. (2020). "Ikhtilaf al-Fuqaha' : Studi Tentang Akar Perbedaan Pemikiran Hukum Islam”, JAS: Jurnal IImiah Ahwal Syakhshiyyah,Vol.2 No. 1, 67.

Attamimi, Abdul Basit, Athoillah Islamy. (2019). "Political Thinking And Attitude Of Religion: Study Of Political Resistance Of Kiai Ahmad Rifa 'I Kalisalak Al-J awi On Colonialism Of The Netherlands", Akademika, Vol.15, No.2, 128-129.

Auda, Jasser. (2008). Maqasid al-Shari'ah as Philosophy of Islamic Law: a Systems Approach, London dan Washington: The International Institute of Islamic Thought, 21-24, 46, 48-49, 54-56, 197-198, 202,

Fadal, Kurdi. (2020). 'Aisy Al-Bahr: "Karya Intelektual Ulama Pesisir Jawa Awal Abad XX Seputar Hewan Laut", Jurnal Lektur Keagamaan, Vol. 18, No. 2, 311, 312, 328.

Fatwa Majelis Ulama Indonesia (MUI) tentang Kepiting ditetapkan pada hari Sabtu, 4 Rabi'ul Akhir 1423 H. / 15 J uni 2002 M, 639-645.

Fatwa dan Tausiyah Majelis Ulama Indonesia (MUI) Provinsi Khusus Daerah Ibu Kota Jakarta (2016), 116.

Ferdiansyah, Hengky (2017). Pemikiran Hukum Islam Jasser Auda, Tesis, Sekolah Pascasarjana Universitas Islam Negeri Jakarta, 105, 111-115, 126-127.

Harasani, Hamid. (2013). "The Role of ljtihad In Progressing Islamic Law In Modern Times", Us-China Law Review, Vol. 10,

https:/ / alif.id/ read/ zaim-ahya/ fikih-kuliner-aisyul-bahri-kitab-ulama-batang-yang-hilang-b213982p/ https:/ / republika.co.id/ berita/ 03yumk1/ kitab-albelut-argumentasi-hukum-halalnyabelut, 1.

https:/ / islam.nu.or.id/ post/ read/ 104682/ ragam-pendapat-ulama-soal-hukum-mengonsumsi-kepiting Islamy, Athoillah. (2017). "Gender Mainstreaming dalam al-Qur'an dan Hadis serta Relevansinya Terhadap Epistemologi Hukum Islam", Jurnal Hukum Islam, Vol.15, No.1, 149.

Islamy, Athoillah. (2020). "Gender Mainstreaming In The Hermeneutics Of Islamic Family Law", Al-Bayyinah: Junal of Islamic Law, Vol.4, No. 1, 28-29. 
Islamy, Athoillah. (2020). "Dinamika Historis Otoritas Hak Kepenghuluan Nikah di Indonesia", Islamitsch Familierecht J ournal, Vol. 1, No. 1, 9.

Islamy, Athoillah. (2021). "Pemikiran Hukum Islam Nurcholish Madjid", Disertasi Pascasarjana Universitas Islam Negeri Walisongo Semarang, 43.

Islamy, Athoillah. (2021). "Landasan Filosofis dan Corak Pendekatan Abdurrahman Wahid Tentang Implementasi Hukum Islam di Indonesia", Al-Adalah : J urnal Hukumdan Politik Islam, Vol. 6, No. 1, 50.

Khallaf, Abd Wahhab. (1947).IIm Usul al-Figh, Kairo: Maktabat al-Da'wat al-Islamiat, 216-217.

Moleong, Lexy J. (2017). Metodologi Penelitian Kualitatif, Bandung : Remaja Rosdakarya, 6

Mudzhar, Atho. (2012). "Tantangan Studi Hukum Islam di Indonesia Dewasa Ini", Indo-Islamika, Vol.2, No. 1, 95-96.

Mustafa, Bisri. (1953).Terjemah Nazam Sulamul Munauraq fi IImi Mantiq, Menara Kudus, 9.

Panduan Karya Tulis IImiah Pascasarjana UIN Walisongo, Semarang : Pascasarjana UIN Walisongo, $2018,35$.

Rasyidi, Aprizal Sulthon (2020). "The Significants and Arguments for the Renewal of Maqacid al-Sharîah", Ulumuddin : J ournal of Islamic Legal Studies, Vol.13, No.1, 46.

Reza, Ahmad Ibnu, Athoillah Islamy. (2020). "Spatial Analysis of Sustainable Land Use Development Coastal Areas in Batang Regency", Bappenas Working Papers, Vol. III. No. 1, 45.

Sarkowi, Agus Susilo. (2020). "Akar Histrois Formalisasi Hukum Islam di Nusantara”, J urnal Sejarah Citra Lekha, Vol. 5, No. 1,14.

Shihab, M Quraish (2013). Kaidah Tafsir, Lentera Hati, 180.

Sunarso, Ali. (2018). "Historiography Of Indonesian Islam", International J ournal of Islamic Studies and Humanities, Vol. 1, No. 1, 10

Supriyadi, Dedi (2007). Sejarah Hukum Islam : Dari Kawasan Jazirah Arab Sampai Indonesia, Bandung :Pustaka Setia, 2007, 5-6.

Yunus, Mammud. (2019). Transmisi Pendidikan Fiqih Nusantara Pada Masyarakat Pesisiri (Telaah Kitab Aisyul Bahri Karya Kiai Anwar Batang), Tesis Universitas Wahid Hasyim Semarang, 1-2, 41.

Zaim/ Muiz, (2018)Sebelum Sidang Komisi, NU Batang Ngaji Kitab Karya Kiai Anwar Batang, nu online :1. https:/ / www.nu.or.id/ post/ read/ 92927/ sebelum-sidang-komisi-nu-batang-ngaji-kitab-kiai-anwar-batang (2019), 1. 